\title{
Gusjigang: An Economic Independency of Citizens in Indonesia
}

\author{
Wawan Shokib Rondli ${ }^{1}$, Endang Danial ${ }^{2}$, Sapriya ${ }^{3}$ \\ \{wawan.shokib@umk.ac.id¹, endangdanial@upi.edu ${ }^{2}$, sapriya@upi.edu ${ }^{3}$ \} \\ ${ }^{1}$ Universitas Muria Kudus, Gondangmanis Bae Po Box 53 Bae Kudus, Indonesia \\ ${ }^{2,3}$ Universitas Pendidikan Indonesia, Jalan Dr. Setiabudhi Nomor 229 Bandung 40154, Indonesia
}

\begin{abstract}
This study has the main objective of conducting an investigation into the benefits of gusjigang for the community (traders) in Kudus. The researchers used the case study method to uncover the reality of gusjigang in Kudus society. The research findings reveal that gusjigang has benefits in the form of economic independence of citizens. Such independence is formed from benefits in a financial and non-financial perspective. The results of this study can be used as a reference for the development of citizenship education, especially the study of civic education on the domain of civic community education, and more specifically on the economic study of citizens. In addition, the development is adjusted to the local culture of each citizen to be more familiar with the culture
\end{abstract}

Keywords: Local Wisdom; Gusjigang; Economic Independency

\section{Introduction}

Gusjigang is an acronym of bagus, meaning good quality (of character), ngaji (learning) and dagang, related to commerce (entrepreneurship) [1] People of Kudus believe that gusjigang is a philosophical teaching conveyed by the Sunan Kudus (syech Jafar Sodiq) [2]. Such teachings are supposed to be preserved as provision in life to improve self and economic qualities. In other words, gusjigang is a knowledge system that has become a living guideline for poeple of Kudus [3]. From this point, gusjigang can be interpreted as local wisdom since it is a philosophical teaching loaded with values to be used as guidelines and preserved. Local wisdom has two forms, namely tangible and intangible. Gusjigang is one of the intagible local wisdom because it is abstract in the form of philosophical teachings manifested in oral tradition for generations. Local wisdom is knowledge and understanding that is believed to have value that can be used to regulate the lives of local people in a wise and prudent manner, and they are preserved [4][5][6].

From the perspective of ethnopedagogy, local wisdom can be a source of innovation and skills that can be empowered for the welfare of society because there is ethnophilosophy [7]. Thus the local wisdom of Gusjigang can be used as one of the innovations and skills to guide the development of education. The implementation can be done in four ways, namely: conservation, restoration, adaptation, and discovery [8]. Local wisdom as a source of value education development has proven to be effective in shaping student character through civic education [9]. The formation of the character of independence in students can be carried out through various forms of activities both spiritually, knowledge transfer and skills training [10]. 
There have been many studies exploring the impact and influence of the local wisdom of Gusjigang, some of which have been linked to financial literacy and customer loyalty. Gusjigang has a significant impact on premarital financial literacy [11]. This proves that the concept of local wisdom gusjigang is a source of knowledge for Kudus people about premarital literacy.

In addition, service quality, customer satisfaction and gusjigang culture have a positive and significant impact on customer loyalty both partially and simultaneously [12]. Nevertheless gusjigang local wisdom will be examined again by accommodating what already exists in order to conduct an investigation of the benefits of gusjigang local wisdom as economic independence for the community (traders) in Kudus.

The main purpose of this research is to investigate the benefits of the local wisdom of the gusjigang for the community (traders) in Kudus. The method used by researchers is a case study to uncover the reality of gusjigang local wisdom in the Kudus community, with the hope that it will be able to uncover the benefits of the gusjigang local wisdom for the Kudus community (traders) on economic independence. The results of this study will be used as a reference for the development of civic education in the domain of civic community specifically in the civics ecconomy study. In addition, the development can be adapted to the local culture of each citizen.

\section{Research Metodology}

This research is a qualitative descriptive study through the investigation of the local wisdom of Gusjigang and exploring its benefits for the community (traders) in Kudus. The study was conducted in Loram Kulon Village, Jati sub-district, Kudus Regency, Central Java Province, Indonesia. Respondents in this study were 12 people, consisting of 1 expert on local wisdom gusjigang, 1 community leader and the rest are traders. The data was obtained through interviews about the understanding of Kudus community (traders) on the concept of local wisdom gusjigang, combined with consistent observations of behavior both as individuals and the community, as well as documentation studies such as the results of previous research and publication of scientific papers relating to local wisdom gusjigang. The data that have been obtained are then analyzed qualitatively by its components consisting of data collection, data reduction, data presentation, and drawing conclusions[13].

\section{Result and Discuss}

\subsection{Benefits of Gusjigang Local Wisdom as Economic Independency.}

The implementation of the local wisdom gusjigang for the community (traders) in Kudus certainly has a goal to be achieved. The purpose of the implementation of local wisdom by the younger generation as a socio-cultural capital for the creation of peace and improving the welfare of the next generation [14]. Thus the implementation of local wisdom gusjigang has benefits for the community (traders) Kudus. The research findings revealed the benefits for the community (traders) in Kudus, namely independence - specifically - in the economic field of citizens. These benefits can be grouped in two points of view, namely: the benefits of Gusjigang local wisdom as independence in financial perspectives and the benefits of Gusjiagang local wisdom as independence in non-financial perspectives. 
1) Benefits of Gusjigang Local Wisdom for Kudus Community (traders) as Independency in Financial Perspective.

Becoming an entrepreneur is the livelihood of the people of Kudus. This choice is motivated by the local wisdom of Gusjigang [15]. As entrepreneurs they have a very important function - specifically - in the economic field (Praag, 2008). The benefit of entrepreneurs in an economic perspective is that there is an increase in income even to national economic development [16]. Increased income in the economy of the community (traders) in Kudus was obtained by implementing the gusjigang local wisdom values in managing the business as a trader. The gusjigang values include: honesty, tolerance, discipline, social care, curiosity, fond of reading, hard work, creative and independent [17]. The character values are internalized in the community (traders) in Kudus, which is manifested in running a business as a trader. From a financial point of view, the benefits of gusjigang local wisdom for Kudus traders are that they get financial wealth, in addition to getting personal satisfaction and fulfilling the necessities of life [18]. Thus the benefits of local wisdom gusjigang in a financial perspective are met economic needs in the family such as the cost of living; children's education costs; saving for the future; provide business capital for children; even to the implementation of the Hajj which for them is the highest achievement of worship. The benefits from the financial point of view in addition to being felt by the community individually can also contribute to regional progress. In the trade sector this has a contribution to the Gross Regional Domestic Product (GRDP) of 80.82 percent so that it becomes a pillar of the economy of Kudus Regency [19, p. 307]

2) Benefits of Gusjigang Local Wisdom for Kudus Community (traders) as Independency in Non-Financial Perspective

A very important finding about the benefits of the local wisdom gusjigang for the community (traders) Kudus as independence in a non-financial perspective, namely: the provision of employment and human resource development. Both are the benefits of the local wisdom gusjigang for the community (traders) Kudus in terms of independence, autonomy, work, increased market share and increased welfare which is the benefits of entrepreneurship from a non-financial perspective [16].

The first benefit of gusjigang's local wisdom for people (traders) of Kudus for the economic independency of citizens in a non-financial perspective was the provision of employment opportunities for the community. The availability of jobs was influenced by the number of companies / industries [20]. In 2017 there were industrial companies listed in Kudus [19]. Thus the availability of jobs for the people of Kudus will have an impact on reducing unemployment.

The second benefit of the local wisdom gusjigang for the people (traders) of Kudus in term of independency in a non-financial perspective was human resource development. The development of human resources was carried out by companies in Kudus through CSR (Corporate Social Responsibility) and creative industry entrepreneurs. Each has different goals, the guidance carried out by the company is aimed at the general public through education and training on entrepreneurship with the aim of the people having the knowledge and skills to become entrepreneurs. This was quite different from creative industry entrepreneurs, where the practice is more emphasized on the development of human resources. The target of human resource development carried out by creative entrepreneurs was their own employees. The goal was that these employees would have the knowledge, character of morality and performance and skills of the creative industry targets have to met. Initially, the 
aim was setting the employees to be able to work in accordance with what was expected by creative industry entrepreneurs, then after a long time working they had the knowledge, attitudes and skills gained from direct education in the workforce. Then after getting their knowledge, attitudes and skills out of work to establish their own creative industries. The development of human resources can inspire the community to become entrepreneurs. This would in turn influence the people of Kudus to choose traders as their livelihood[20]. Thus the benefits of local wisdom gusjigang in a financial and non-financial perspective could shape the economic independency of Indonesian citizens, in this case the people (traders) of Kudus

\section{Conclusion}

Starting from the findings and results of the discussion it was revealed that the local wisdom of the gusjigang has the benefit of the economic independence of Indonesian citizens, in this case the people (traders) of Kudus. This independence was formed because the people of Kudus carried out the gusjigang values in conducting their business as traders. Thus, the local wisdom of Gusjigang was financially beneficial to meet economic needs such as living costs, children's education costs, saving money, providing financial capital for children even to the implementation of the pilgrimage (Hajj) - the highest level if the religius practice - for the people of Kudus. While the benefits of a non-financial perspective are the availability of jobs and coaching to increase human resources.

\section{Acknowledgments}

Our deepest thanks to the Ministry of Research, Technology and Higher Education and the Ministry of Finance through LPDP for providing scholarships to complete this doctoral program research. This article is part of a doctoral dissertation research program at the Department of Citizenship Education at the Graduate School of Universitas Pendidikan Indonesian.

\section{References}

[1] A. Jalil, "Spiritual Entrepreneurship (Studi Transformasi Spiritualitas Pengusaha Kudus)," Institut Agama Islam Negeri Sunan Ampel Surabaya, 2012.

[2] N. Said, "Spiritual Entrepreneurship Warisan Sunan Kudus: ModalBudaya Pengembangan Ekonomi Syari'ah dalam Masyarakat Pesisir," Equilib. J. Ekon. Syariah, vol. 2 No.2, pp. 226-242, 2014.

[3] W. S. Rondli, "Kewirausahaan Berbasis Kearifan Lokal Gusjigang: Sebagai Alternatif Mulok Untuk Penanaman Karakter Kemandirian Warga Negara," in Penguatan Muatan Lokal Bahasa Daerah sebagai Pondasi Pendidikan Karakter Generasi Milenia, 2019, pp. 125-134.

[4] A. S. Keraf, Etika Lingkungan. Jakarta: Penerbit Buku Kompas, 2002.

[5] A. Nababan, Pengelolaan Sumberdaya Alam Berbasis Masyarakat Adat. Pelatihan Pengelolaan Lingkungan Hidup Daerah. Bandung: Pusat Penelitian Lingkungan Hidup IPB, 2003.

[6] S. Sartini, "Menggali kearifan lokal nusantara sebuah kajian filsafati," J. Filsafat, vol. 37, no. 2, pp. 111-120, 2004.

[7] C. Alwasilah, Etnopedagogi: Landasan Praktik Pendidikan dan Pendidikan Guru. Bandung: Kiblat Universitas Pendidikan Indonesia, 2009.

[8] T. Singsomboon, "TOURISM PROMOTION AND THE USE OF LOCAL WISDOM THROUGH CREATIVE TOURISM PROCESS,” Int. J. Bus. Tour. Appl. Sci., vol. 2, no. 2 , pp. 32-37, 2014. 
[9] E. Elan, S. Sapriya, and A. Abdulkarim, "Development of Values Transformation Modes of Local Wisdom of Baduy Culture to Form Student Character through Civic Learning in Elementary School: A study of Attitude of Elementary School Students in Kasepuhan Citorek Adat Area, Lebak Regency, Banten Province," in Proceedings of the Annual Civic Education Conference (ACEC 2018), 2018.

[10] F. Febriyanti, I. Affandi, and E. Danial, "Model Economic Development of Civics in Character Formation Plus Entrepreneurial Behavior-Based Self-Reliance in the Pesantren," in Proceedings of the Annual Civic Education Conference (ACEC 2018), 2018.

[11] S. Mulyani, "Peran Gusjigang dan Penerapan Akuntansi Terhadap Literasi Keuangan Pra-Nikah,” J. Din. Ekon. Bisnis, vol. 12, no. 2, pp. 159-172, 2015.

[12] U. Himawati and S. D. W. Prajanti, "Pengaruh Kualitas Layanan, Kepuasan Pelanggan dan Budaya Gusjigang Terhadap Loyalitas Pelanggan," Econ. Educ. Anal. J., vol. 6, no. 3, pp. 865-876, 2017.

[13] M. B. Miles and M. a. Miles, M.B. \& Huberman, Qualitative Data Analysis An Expended Sourcebook, Second Edi. London: SAGE Publications, 1994.

[14] R. Sibarani, Kearifan Lokal Hakikat, Peran, dan Metode Tradisi Lisan, Pertama. Jakarta: Asosiasi Tradisi Lisan, 2012.

[15] M. Mustaqim and A. Bahruddin, "Spirit Gusjigang Kudus dan Tantangan Globalisasi Ekonomi," J. Penelit., vol. 9, no. 1, pp. 19-40, 2015.

[16] B. Luke, M. L. Verreynne, and K. Kearins, "Measuring the benefits of entrepreneurship at different levels of analysis," J. Manag. Organ., 2007.

[17] M. Maharromiyati and S. Suyahmo, "Pewarisan Nilai Falsafah Budaya Lokal GUsjigang sebagai Modal Sosial di Pondok Pesantren Entrepreneur Al Mawaddah Kudus,” J. Educ. Soc. Stud., vol. 5, no. Vol 5 No 2 (2016): Desember 2016, pp. 163 $172,2016$.

[18] M. A. Hitt, R. D. Ireland, D. G. Sirmon, and C. A. Trahms, "Strategic Entrepreneurship: Creating Value for Individuals, Organizations, and Society," 2012.

[19] Kudus Regency In Figures 2018. Kudus: Statistic Of Kudus Regency, 2018.

[20] C. M. van Praag and P. H. Versloot, "The Economic Benefits and Costs of Entrepreneurship: A Review of the Research,” Found. Trends ${ }^{\circledR}$ Entrep., vol. 4, no. 2, pp. $65-154,2008$. 